\title{
RITES OF PASSAGE IN INITIAL TEACHER TRAINING: RITUAL, PERFORMANCE, ORDEAL AND THE NUMERACY SKILLS TEST
}

\author{
Olwen McNamara, Lorna Roberts, Tehmina N Basit \& Tony Brown \\ Institute of Education, Manchester Metropolitan University
}

\begin{abstract}
'Transition' was identified by cultural anthropologists in the early $20^{\text {th }}$ century as the liminal stage of a 'rite of passage'. Contemporary anthropology challenges the structural nature of these classic interpretations of ritual and analyses them as 'performance theory': 'social drama' (Turner), 'dramatism' (Burke), 'interaction rituals' (Goffman) and 'ritualisation' (Bell). In applying a contemporary anthropological lens to Initial Teacher Training we identify the transition not as a linear progression but as a complex process of extended and ambiguous 'in-between-ness' that involves play, performance and ordeal. We depict preservice teachers enmeshed in the performance of symbolic acts and the undertaking of 'ritual ordeals'; and report how they narrate their passage as a complex 'game' of 'being' and 'becoming' and portray the holistic experience metaphorically in terms of 'play'. We explore, in particular, students' perceptions of the Numeracy Skills Test - the most recently imposed 'ritual ordeal' (a 'rite of intensification') - characterised by government as a device to police the boundaries of the teaching profession.
\end{abstract}

Key words: ritual, play, performance, ordeal, Numeracy Skills Test, Initial Teacher Training.

\section{Introduction}

Classic anthropology conjectured a universal sequence in ceremonial transitions characterised by three phases: separation, transition and reincorporation (or preliminal, liminal, post liminal - before, at and past the threshold). In his seminal work, Les rites de passage (1909), the French anthropologist, Arnold van Gennep, identified and systematically recorded the sociocultural features of such transitions. In the first phase of passage van Gennep depicted the individual as symbolically severed from a previously fixed point in the social structure and entering as traveller into the second, suspended or liminal, phase between past and future identities. The traveller, upon successful negotiation of this second phase, would cross the threshold and be (re)incorporated into society with a newly designated status. Commonly transition was associated with biological/life cycle crises such as childbirth, coming of age, marriage and death and its sociological function was to manoeuvre an individual from one status to another. Passage was, in some cases, as a result of, rather than the cause of the ceremony. Characteristically such rites and ceremonies are rich in symbolism and often entail ordeals, distinctive garments, feasts/functions, ritual customs and taboos.

White (1989: 177) adopted this classic anthropological framework to depict the preservice teacher's education in the USA as a 'rite of passage'. 'Separation' required students to "cut the ties that bind them to the ordinary world" of college in order to embark upon the student teaching semester. Symbolic rituals undertaken by students in preparation for this embarkation included 'getting their haircut', 'dressing in smarter clothes', 'adopting different names (Sir/Miss)', 'parting from college peers' etc. Whilst on teaching practice the students were inducted into a "specialised body of knowledge unique to the professional community": acquisition of tenets, technical knowledge and reflective skills. Upon their return to college they were "ritually reinstated in the ordinary world with accompanying changes in status rights and prerogatives". Reincorporation was signified by a 'wine and cheese' function ('Holy Communion' in playful congress) and having been lauded for surviving the ordeal students were acknowledged as having changed in relation to college peers who had not yet undergone ritual induction into the 'real world' of the classroom. 
Exploring the applicability of White's three-stage schema as a learning theory in relation to teacher education Eisenhart (1991) found it an inappropriate model, in certain ways, for the programme at her college. In particular, rather than creating experiences that were consistent and persuasive - a coherent ritual transmitted through a 'specialised body of knowledge' - she found the programme endorsed inconsistent goals and created confused messages. Head (1992), also exploring the use of anthropological models to inform teacher education programmes, identified student teachers as "no longer just students but nor are they fully teachers... separating from their previous roles as students and preparing to embark upon their teaching careers" (ibid: 94). She proposed 'growing' as a useful anthropological metaphor through which to understand teacher education as a transformative experience and advocated that students should be helped to develop a sense of their own personal educational philosophy.

We portray transition as captured neither by the linear model of White nor by the "no man's land' posited by Head. Instead, we see Initial Teacher Training (ITT) as a more deeply complex liminal stage of passage in which student teachers in their narrative autobiographies story the complex dynamic student/university/school/government in a way that inscribes them as neither one thing nor another, and yet both at the same time. We develop this analysis using a performance theory frame to the study of 'symbolic acts' and 'ritual ordeals' enacted by the students. We present data from a study in the UK of final year BEd students [1] whose 4 year course programme is university-based and includes periods of school placement in each year. On the threshold of 'teacherdom' they are depicted as experiencing the final stages of transition as a series of ritual ordeals that both signify and legitimate their passage into Qualified Teacher Status (QTS).

In the first section of the paper we take a detailed look at just one of these ritual ordeals, the recently imposed QTS Numeracy Skills Test, and we present survey and interview data [2] to illustrate how students perceive it 'meaning' and 'doing'. Moving from the particular to the general in the second section of the paper we take a holistic look at the ITT process to illustrate how students engage in ritual practices and symbolic acts whilst shifting between positions of 'being' and 'becoming' a teacher. We explore what it means for these individuals to experience such shifts through the interplay between notions of 'ritual', 'play', 'game' and 'performance'. Finally we look in particular at the 'real'/'ideal' dichotomy as experienced at both contextual and psychological levels and expose the way in which it reveals the 'inner' and 'outer' realities of students' lived experience.

\section{QTS Numeracy Skills Test as cultural performance}

Performance theory challenges traditional structural analyses brought to the study of ritual. Schechner (1977) and Goffman $(1969,1972)$ both present ritual as an act. Turner (1987: 75) makes the distinction of depicting performance as a "complex sequence of symbolic acts". Such acts, he observes, involve social and psychological processes and, as a consequence, should be studied in context and in chronological relation to other events (Turner, 1982). Turner, Goffman, and in particular Schechner, draw on the theatrical paradigm to make links between 'social drama' and 'theatre'. Performance theory also draws on a wide range of other cultural activities such as sport, play, public spectacles etc. (e.g. MacAloon, 1984). Many have used these analogies to transgress the boundaries between the ways in which sacred and secular ritual activities are interpreted. Portraying school effectiveness discourses in terms of cultural performance Stronach (1999: 173) explores the ways in which such discourses "especially in their mediatized forms - as league tables - are a form of contemporary spectacle" and examines how "the technical discourses obscure elements of ritual, philosophy, myth and shamanism". In this section we depict the QTS Numeracy Skills Test as just such a 'contemporary spectacle'. We depict it not simply as an artefact, representative 
in this case of the 'audit explosion' (Power, 1994, 1997), but also, as a cultural performance, an agent of change - not so much "reflective as reflexive" (Babcock quoted in Turner, 1987: 24).

It was, we are told, an "overwhelmingly favourable response" to proposals in the Green Paper 'Teachers: meeting the challenge of change' (DfEE, 1998b) that persuaded Estelle Morris, Minister for School Standards, to introduce skills testing in the Autumn of 1999. Her intention was to "raise the skills levels of the teaching profession" and thereby "raise further [students'] own professional standing and the profile of teachers and teaching" (Morris, 1999: 3). Student teachers equipped with said document and credential would, it was envisaged, become change agents "instrumental in raising standards of teaching and learning in our schools and in contributing to the changes needed to extend opportunity for young people and the wider community" (Morris, 1999: 3). The proposed numeracy test was, in particular, intended to police the boundaries of the teaching profession by ensuring that "every one qualifying to teach has a good grounding in the use of numeracy in the wider context of their professional role as a teacher" (TTA, 2000: 2).

Such an event would be defined by MacAloon (1984) as 'metagenre': "an increasingly hybrid form of contemporary ritual involving the dramatic enactment of major social concerns, publicly shared and articulated" (Stronach, 1999: 183). MacAloon conjectures that the "growth of the spectacle genre in the modern world is to be understood as a public form of thinking out, of telling stories about certain growing ambiguities and ambivalences" (MacAloon, 1984: 247, quoted Stronach, 1999: 183). The 'social concern' that prompted this particular 'contemporary spectacle', for example, was focused on the quality of mathematics subject knowledge and understanding of teachers. Energised by government rhetoric the 'concern' developed in reaction to interpretations of comparative international studies of pupil outcome data [3] and was sustained by a burgeoning national audit culture of league tables and targets (Stronach, 1999), to which the 'numeracy skills' levels of pre-service teachers will undoubtedly soon be added.

The Numeracy Skills Test was enacted as a very public theatrical event orchestrated by the Teacher Training Agency (TTA). Information, advice, instruction and support was made directly available through web site, information line (by telephone, fax and email) and publications. "The cultural content of a tradition is organised and transmitted on particular occasions through specific media" (Singer, 1959 p.xii, 1972) and this event was clearly no exception. Each student teacher received from the TTA a substantive support pack (TTA, 2000a) containing information, numeracy support and sample questions. Individual rehearsals were managed by means of hi-tech 'cultural media' and entailed students undertaking practice tests available as 'web-based resources'. A number of students, such as the one who claimed, "I've been doing those tests on the Internet and though they were hard, you know, I've done about five now and each time my score has improved", took such rehearsals very seriously. Students were (re)assured, however, that amidst all of this 'state of the art' telematics ITT providers would be kept "in touch with developments" (Morris, 1999) [4].

Thursday $1^{\text {st }}$ June was to be the National Premiere and as the day drew near detailed local planning was evident in numerous venues around the country...

In some social settings ritual performances are part of ecosystems and mediate political relations, group hierarchy and economics; in other settings ritual performances begin to take on qualities of show business (Schechner et al., 1976: 210)

The following scene is set at the Institute of Education, Manchester Metropolitan University Didsbury Campus (one of the largest Initial Teacher Training providers in the country)... 
The initiands: 830 pre-service teachers.

The audience: (absent but 'overwhelmingly positive') The Great British Public who never 'forgets a good teacher' (TTA 1999).

The stage(s): 34 rooms across the Campus. The largest held 120 the smallest 16, there was a room for dyslexic students and one for non-native English speakers. The room for latecomers held 24 and an allowance was made for an overflow of 16.

The script: written by the TTA 'in conjunction with specially contracted experts in the field' remained undisclosed to the initiands until the performance.

The rehearsals: managed individually through 'web-based resources' focused on initiands' use of numeracy in the 'wider context of their professional role as a teacher'.

The directors: worked solidly for days prior to the performance enlisting back stage support, planning, producing room lists, counting out scripts (lack of sufficient spares made contingency arrangements exceedingly tricky); preparing individualised instruction packs for the stage managers/runners; stopping builders from building, gardeners from cutting lawns, and beer lorries from delivering.

The stage-managers: 40 invigilators and 20 runners (provided with mobile phones due to the size of the campus) were drawn from amongst the academic and administrative staff.

The stagehands: a House Services team worked tirelessly for days setting out the requisite amount of chairs and tables in the 34 rooms and ensuring security and access.

The props: providing audio equipment for each room, above and beyond what was already available cost $£ 1000$. Backup calculators, pens, rulers, paper cups and water were also supplied in great numbers.

The pre-performance briefing: planned, according to the director, with "military precision" took place in Lecture Theatre A at 10.15am.

The performance: almost faultless - the stage managers reported only one audiocassette to be mal-functional. Only 2 of the 830 initiands were late and a further one reported with a slight malaise at the beginning of the performance (most probably a case of stage-fright). Less impressive, however, was that one in ten of the initiands forgot their Department for Education and Employment (DfEE) number and/or their photographic identification (a problem in the offing!)

The post-performance debriefing: took place again in Lecture Theatre A where slightly less 'military precision' was apparent due to the unexpected presence of about 80 initiands under guard until such time as they could be reunited with their scripts and DfEE number and/or be identified by an official. Scripts were cross-checked against attendance; missing scripts checked against the absentee list; unused scripts, as instructed, returned forthwith to the TTA. The reviews: The director proclaimed "the whole thing was an amazing production". The initiands' whose views were canvassed [2] proved to be less enthusiastic. Approximately half found the oral test easy or at least fairly easy; less than $10 \%$ rated it hard. Most felt the written test passable when it came to level of difficulty, although a few complained it was "wordy, a lot of looking at tables"; about 10\% rated it quite hard. The time allowed for both written and oral tests was an issue for many. Opinion was equally divided as to whether there was, or was not, sufficient time for the oral test. When it came to the written test, however, nearly twice as many students felt the timing too tight as were comfortable with it. When measured against the other 4 or 5 performance indicators employed on their course, however, the tests got a massive 'thumbs down' - $90 \%$ of students rated it 'least important/valuable'. 
The use of performance metaphors and analogies allows us to focus upon what ritual actually 'does' as well as what it 'means'. Bell's 'ritualisation', for example, carries with it a 'processual' aspect of ritual action that focuses on the 'effects upon the world'. As a cultural performance the test was 'reflexive' as well as 'reflective' in that it functioned both to provoke and record the transition of the initiand, and in this next section we report students' perceptions of the performative aspects of the skills test.

Most students read the test first and foremost in terms of its (re) positioning of other previously existing symbols of passage. A few students regarded it as a legitimation of their mathematical subject knowledge and thereby their transition into 'teacherhood': "a good idea to say who can do maths to a standard"; "I don't know if it will influence my development as a teacher as such but it will just prove that you have got the knowledge needed to teach". Most frequently, however, students perceived the test as degrading other 'symbols' of their proficiency in mathematics. Maths GCSEs, A levels, numeracy skills audit etc. were all felt to be debased: "I feel it makes a mockery of the degree"; "It undervalues O-levels, A-levels, work experience, access to get onto the course - undervalues everything".

Many orthodox initiation rites begin by stripping initiands of previously held symbols of status and power. Goffman (1961) identified a 'mortification' theme at work in the induction process in 'total institutions' such as asylums, the armed forces etc:

the recruit comes into the establishment with a conception of himself made possible by certain stable social arrangements in his home world... upon entrance he is immediately stripped of the support provided by these arrangements... he begins a series of abashments, degradations, humiliations and profanations of self (Goffman 1961: 24).

Sinclair (1997: 15) extended Goffman's notion of 'closure' as 'physically bounded space' to encompass institutions that were 'conceptually bounded' and 'cognitively limited' such as medical schools:

Their unceasing need to work for unceasing examinations set by different professional segments will ultimately result in professional cognitive membership of the institution of which they are an inmate (the profession of medicine), a passage and a membership that may exclude the lay world just as surely as asylum walls.

Goffman's 'total institutions' did not look for 'cultural victory' over inmates but they sought to establish a tension between home and institutional worlds that they could use in the 'management of men' (1961: 23-24). Many students, similarly, saw the test as a wielding of power with respect to themselves: "It's another hoop to jump through"; "I think that they're saying that they have... they have a hold I think the government like to have a hold over us". A number of students also read the test as symbolising government control over ITT providers. The direct imposition of the test by the government on to the students was felt to marginalise university tutors who merely delivered the rigidly scripted performance: they were seen to lack any degree of agency in the matter with regard to validation/timing/content etc: "it was just a mystery to the tutors as well". Some students felt the tests could potentially prove a 'hostage to fortune': "the government has a stick to beat HE institutions".

As an ordeal the test proved highly effective: neophytes experienced the fear, powerlessness and humiliation befitting of a 'mortification' process. Yet they did not subscribe to remaining silent in the face of ritual torment. Students reported overwhelmingly negative responses to their ordeal. The test produced a considerable amount of anxiety: "the 
amount of worry that that has instilled in quite a lot of people is really really worrying"; "Nervous stressed sick"; "I was vomiting before it".

Students were also annoyed because it was seen to be "unfair", they felt "used like a GUINEA PIG", "irritated", "it is totally pointless, if you're on the course you've proved your ability", "can I swear?" This sense of grievance was quite apparent in the attitudes of most students and a number of substantive themes could be identified. The main thrust of the aggravation was that the goalposts had been changed:

I'm all for change and making things better, but the goal posts have been moved so much, I mean since I've been here, you know, everything's been moved. Now we're having this numeracy test and we didn't know we were having that.

Secondly, the "suddenness" and "unexpectedness" with which the test was "just sprung on us" in the final year was undoubtedly a 'bone of contention': "I think it is a pain that they have introduced it for our year at this late stage - bang, tough, you got a test!" Thirdly, the "timing" of the test, negotiated it was claimed (TTA, 1999) with ITT providers, was not to the liking of students: "it's more pressure especially at this time when we have so much work to do". Most students were of the view that, if necessary, it "would be beneficial before being accepted on to the course not at the end". Finally, and importantly, the validity of the test was challenged by many students. Not apparently aware that it was intended to examine their use of numeracy in their 'wider professional role', some neophytes refused to accept the legitimacy of the test as a transitional ordeal complaining that it was not testing the broad spectrum of mathematical subject knowledge relevant to National Curriculum Key Stages 1 and 2. It was felt to include few "important" areas of the primary maths syllabus: "it's not about teaching maths it's about how to organise statistics". Additionally, the relevance of doing such questions under pressure of time and/or orally was challenged: "you won't do these types of questions orally anyway". On the whole most students were extremely doubtful, it has to be said, as to whether the test would improve their classroom practice: "I mean obviously because I've done them, I'll know the subject knowledge but I don't think it will make much difference on the way I am in the classroom." So the test was experienced at one and the same time as both very 'real', as evidenced by the emotional and psychological traumas it generated, and yet also 'unreal', as reflected by its perceived lack of methodological relevance and validity in respect of both the course and the students' professional life.

For most students, however, the test was a source of considerable motivation to acquire subject knowledge and in this way the change provoked was simultaneously the 'cause' and the 'result' of passage. As students observed: "obviously both we and the children we teach will benefit" and "It's a good idea because, you know, it encourages you to brush up on your maths". The perceived need to improve subject knowledge leaked into concerns about accountability: "[we] can do this and therefore [we] are now accountable"; "I can see why they are doing it. I can see there's got to be a national standard and teachers have got to be at this set standard to be a teacher for the sake of the children". This acceptance of the mantle of responsibility directly from the government simultaneously reinforced the marginalisation of ITT providers as erstwhile guardians of the standards of NQT.

Positioning the test as a 'rite of intensification' many students depicted the government as a gatekeeper policing the boundaries of the teaching profession in order to prevent inadequate teachers from entering:

I know the government are obviously worried about teachers that are in the 
school at the moment, some of them that don't know their subject knowledge and... which is fair enough, I mean, I would hate for my children to be taught by teachers that didn't know what they were talking about

A number of students were themselves sympathetic with such an ambition and regarded the test as a necessary, and potentially effective, gatekeeper:

I think they're a good idea because without sort of being bitchy or derogative or anything like that I do think there are a lot of people on our course and I personally know plenty of people who simply have ... shall we say even in year 6 class wouldn't have the mathematical knowledge to teach them.

Although the performance demonstrated a mix of control, paternalism and impressive organisational ability it was orchestrated in such a way as to undermine its own authority by denoting a degree of incompetence and indecent haste, in the eyes of some students:

Suddenly we are told six months before we finish that we have to do a maths test in June and it is not a lot of time for preparation, to get ready for it. And I don't even know what the pass rate is. Just seems so disorganised.

Finally, a great many students read the test as a popularity gimmick - a ploy perpetrated by the government in order to increase their popular esteem:

Ooh, you know, we're really panicking, we're going to have a general election in a couple of years time and people are worried about the state of our schools... We'd better throw some maths tests in... I'm very cynical ...they'll stand up there and they'll say 'Ooh our schools are rubbish' ... and then they worry because everyone thinks that schools are rubbish and it's because they've told them that... it's stupid, so yeah, these tests are just for popularity at the moment I think, definitely. I think it's very crafty to put them in now, very vote-winning.

Such data depict vividly one student's 'machiavellian' reading of the government's polemic about teaching/teachers as designed to incite in the electorate 'social concern' about standards of education whilst rhetorically demonstrating government anxiety, and simultaneously, presenting government with the opportunity to act effectively to resolve the crisis. Contemporarily described as 'harlequinading' [5] - the Numeracy Skills Test is presented as a spectacle enacted for an audience absent from the performance.

\section{Liminality as play: 'it's a let's pretend situation'}

The 'framing' of the Numeracy Skills test as a 'performance' indicates its deliberate difference, its 'unreality', but it also "confers on the performance the ability to signify or denote larger truths under the guise of make-belief situations" (Bell, 1997). In the same way a number of other transitional activities, such as school placements, can be read as 'rehearsals' for the student's future teacher identity. Rites of passage are inherently dramatic because the "participants not only do things, they try to show others what they are doing or have done; actions take on a performed-for-an-audience aspect" (Turner, 1987: 76). This is particularly true of students on teaching practice who have to demonstrate to tutors, class teachers, parents and pupils their ability to perform in a 'teacherly' way. Yet most students experience teaching practice as a continual shifting between positions of 'being' and 'becoming.' We 
now present data that illustrate how students' accounts capture ontological dualities of: 'being' and 'not being'; 'real' and 'not real'; as well as contextual dichotomies between 'school' and 'university'. We also illustrate how they situate these dilemmas in the interplay between 'ritual', 'play', 'game' and 'performance'.

One student talking about her development as a teacher explained her evolving identity as "crossing a line". On one side of the line, she lacked "confidence, knowledge and understanding"; the nearer she got to the line her confidence and knowledge increased, then she started to "cross over the line....". This account implied the staged transition posited by van Gennep, however, the majority of students did not experience the shift from student to teacher in this way. Most of the students' narratives inscribed their dual identity as student and developing teacher, thus positing a state of in-betweeness: "it's sort of flipping in between the two". One moment they are a 'student' and the next they are a 'teacher': "I was their teacher again and you walk away and you're back to being a student"; "I feel like a teacher when I've got my teacher clothes on, ... but when I'm walking down the street I just feel like a student".

For the majority of students being in school and performing "the general things a teacher would do, like daily duties, like the register, collecting the money, dealing with problems" bestowed teacher status. In the process of rehearsing the role of teacher the student performs symbolic acts and behaviours associated with that role. The performance of ritual and symbolic acts is "transformative ... revealing major classifications, categories, and contradictions of cultural processes" (Turner, 1987: 75) and through it socio-cultural groups adjust to change, and adapt to their environment. In relation to school placement the professional symbols associated with the teacher's role include such things as dress, particular behaviours and language:

It was just... getting up in the morning, getting dressed, putting on something [so] that I looked like somebody, doing my hair and then struggling with the books and the briefcase and all the things that I need for the day... and then from that point when they came in, in the morning and said good morning and I took the register, that's when I felt like a teacher.

Here we have examples of the symbols that signify teacher status. The sartorial appearance of the ceremonial robes: getting dressed to look like 'somebody', 'doing my hair'. The canticles and responses prescribed in the rites: verbal refrains associated with teaching/ learning behaviours such as 'good morning everyone', 'good morning Miss Smith'. The wielding of instruments of surveillance such as 'taking the register' and, finally, 'books' and 'briefcase': the symbols of power and knowledge often subsumed in myth/ritual.

A few students identified autonomy and responsibility as factors that initiated episodes of 'teacherlyness'. This was evident when students were left to use their own initiative; allowed to work independently and perform without guidance: "I was running the show", "I feel the teacher isn't having to help me like in past times... I just think I will do it this way". Not being "floored", being able to "cope" with a situation and "manage", being able to devise and apply appropriate "strategies" all contributed to a positive effect in terms of teacher identity. Having a sense of responsibility for what transpired in the classroom, a sense of having effected a change in pupils' behaviour also impacted positively on the students' images of their teacher self: "how the children responded and what they learnt, I felt it was down to me." Indeed most students claimed that it was the children who made them "feel like a teacher". This was particularly noticeable in the cases when students had complete control of pupils; "I've taken them for a whole day, that makes me feel like a proper teacher". Not only did pupils 'bestow the gift' of 'teacherhood' (McNally et al., 1994), but positive 
interactions with colleagues and parents, also helped to confirm teacher identity: "I know the parents see me as a teacher."

Despite experiencing episodes when they felt like "the real McCoy" students paradoxically, and at times almost simultaneously, experience moments when they recognised that they were not a 'real teacher'. A number of students, revealing the interplay between 'being' and 'not being', referred to themselves as "not the proper teacher". For one not being able to "do things like playground duty" reinforced her image of herself as student. For most students periods spent in university denied their status as teachers and reinforced their student identities. A number recognised the irony of being taught to be a teacher by being positioned as a 'pupil' doing mathematical tasks, or, as a 'student' learning mathematics. Rarely, did they report during university sessions being positioned, or treated, as a teacher.

A number of students, both young and mature, depicted their teaching practice in terms of 'playing'. Turner portrayed his experience of ritual as a performance which was "antistructural, creative, often carnivalesque and playful" (Turner, 1987:7). The performance was 'antistructural' because existing structures could be overturned to "play with the elements of the familiar". 'Playing' here is represented as a 'doing' through which one is able to be creative and, as a result, 'novelty emerges': "in liminality, new ways of acting, new combinations of symbols, are tried out, to be discarded or accepted" (Turner, 1977: 40). In terms of students' transition to primary school teachers the ritual performances are intended to enable the initiands to develop effective 'teacherly' behaviours. 'Play' denotes 'fun', 'game', 'freedom' and 'performance' (Turner 1987: 33-34). Underlying the frivolous nature of ritual play, however, is a serious intent. In ritual performances 'joking is fun' but also entails a 'social sanction' (Turner 1982). Caillois (cited Turner, 1982: 125) presents two poles of play: 'paida', childlike involving free improvisation and 'uncontrolled fantasy'; and, 'ludus', more organised and performed as a "training for coping with day to day obstacles in life". Student accounts reveal just such a number of levels of play. One described her school experience as 'a big game' the nature of which was revealed to be reminiscent of childhood games: "when you are playing hospitals... or you play secretaries" but this time the student was 'playing school'. The 'play' here represents the creative aspect of ritual in that the student is rehearsing the role of teacher, experimenting with teacherly behaviours to develop strategies which could be taken forward or rejected: "let's try that, trying out playing with things like the strategies and techniques and stuff, until you get it right".

The student is 'free' to make mistakes protected by the 'safety net' provided by the class teacher and university tutor: "at my last placement you were the teacher, but you still had somebody behind you and if anything went wrong they were there". During liminality initiands are "temporarily undefined, beyond the normative social structure", consequently they have "no rights over others" and are free from structural obligations (Turner, 1982: 27), hence the freedom to 'try out' and 'play' with possibilities. However, the experiences of most evolving teachers shows that the 'special freedom' (Turner, 1982:26) is somewhat curtailed, and play is much closer to the 'ludus' axis. Turner (1987:28) observes that "when implicit rules begin to appear which limit the possible combination of factors to certain conventional patterns, designs, or configurations... we are seeing the intrusion of normative social structure". Likewise students are not entirely free to indulge in their own fantasy of teaching, there are associated 'social sanctions' (Turner, 1982). Students, for example, endure a number of 'tests' to determine their suitability for reincorporation into society as a teacher. Governed by demands of school, university and government they have to satisfy national and local criteria: subject audits, National Standards for QTS, university assignments and examinations etc. There can be serious consequences for the aspiring teacher if the rules of the game are transgressed: entry into 'teacherdom' can be denied. The community at large 
can also suffer during the initiation process as some students recognise: "I would hate any child to feel a failure or ... stupid because of the way I taught them"; "I am still questioning myself, have I taught it the best possible way? Am I failing these children or am I helping them with their maths?"

\section{'Real'/'ideal' dichotomies in 'inner'/'outer' realities}

In acting out their role as teacher the lived reality of students' professional identity collides with the unreality of rehearsal and they begin to reconcile their own beliefs and attitudes about teaching with the diverse external perspectives and prescriptions from university, placement schools and government. In doing so students attend to aspects of reality that they value as important to their goals. Many students valued and privileged the 'real' world of the classroom in preference to the 'idealised' world of university: "you hear phrases constantly from teachers: "when you join the real world...". Ideal/real in this sense also correlated to notions of theory/practice with university representing the theory and school the practice:

you've got the practitioners who are doing the job and you've got the university, the theorists, who are sitting there with all the books and the literature... then in practice there are other teachers who are working more practically with it trying to implement on a practical level rather than a theory level.

Students experienced university and school as two distinct worlds. One student observed that the alleged partnership between university and school was all but virtual: "so you've got two ends and we are in the middle". Many perceived the two worlds as having different rules depending upon where one was positioned. These competing agendas often presented students with dilemmas (c.f. Eisenhart, 1991):

I had to go with the school because I was working there at the time and also I got this criteria to meet for college... it's only because I had such an understanding tutor because otherwise that could have easily failed me

Many students did not recognise the 'school' world as presented by university. 'I don't think any school I have been into matches what the college says...." The 'real' world of the classroom was experienced by students as unpredictable, messy, and constrained by a number of factors:

Before we went on placement we had lessons here and you watch these videos and you think, 'I will never be able to do that', because they are perfectly swinging the pendulum and they are doing all this, that and the other...Then you go round the school and you see how they are teaching it $\ldots$ is nothing like the video, it is nothing like the college is telling us to do it at all. They haven't got the resources to do it that way.

Whilst rehearsing the teacher role, students were fully engaged in 'playing school' but they also had to step outside that game and enter a different one namely, 'what is a teacher?'. This new game involved initiands measuring their performance against an ideal or fantasy of teacher behaviour and learning to define and shape themselves against this 'ideal': "Initiation is like a play with some idea of the 'ideal' usually involved" (La Fontaine 1985 quoted in Stronach, 1988: 62). Student, school, university, and government, however, were seen to present different and very diverse perspectives about what this 'ideal' might entail. For 
example, the government ideal might be characterized by auditable competences and criteria relating to techniques, knowledge and skills such as that outlined in the National Curriculum for Initial Teacher Training (DfEE, 1998), the Standards for QTS (TTA, 1997) and the Career Entry Profile (TTA, 1997). For many students, however, notions of 'ideal' types were bound up in the personal: one felt she could teach "without the criteria" because of the person that she felt she was; another felt that meeting criteria would not tell her "what sort of teacher" she was. There was evidence that many students complied resignedly with the Standards: "I view a lot of the things we have to do unfortunately with the ...view that... it's just another thing that we've got to do".

Yet 'real' and 'ideal' at times co-existed uncomfortably. Students performed the role of teacher when they had not fully acquired the necessary expertise. Such expertise can only come from experience yet, paradoxically, students must present an image of themselves as already having the appropriate knowledge and skills in order to gain that experience. Performance is measured against an 'ideal' and it is precisely because of this that the initiand, with limited experience, often fails to recognise her/himself:

We have worked through these audits and I have been looking at the criteria and I can meet them to a certain extent but I don't think you can truly develop them all until you are a practising teacher ... I see the audits as work, they are the work, I have done the work, ... and yet I am still a person away from them, it is like a different person who has done all that work, ... It is like two separate things and they don't really go together yet.

Measuring oneself against an 'ideal' reveals dichotomies between 'inner' and 'outer' realities (Winnicott, 1980). For the student above the inner reality is her 'lived experience' and she is trying to reconcile this 'inner' reality of who she is with the 'outer' reality of the competences against which she is judged. Many students experienced a cognitive dissonance between inner and outer realities. Psychologically the student above did not recognise the "person who has done all the work" she was " a person away from them". In the classroom space the student was trying to create her teacher-identity through play for, "it is in playing and only in playing that the individual ... is able to be creative and to use the whole personality, and it is only in being creative that the individual discovers the self" (Winnicott, 1980: 63). It is through just such interactions with others that the identity is given or denied substance, as when pupils bestow the gift of teacher identity (Goffman, 1969).

Cultural performance also carries with it a reflexive aspect: the performer is at one and the same time subject and object. This divided self 'is' and 'sees' and 'acts' upon itself as if it were an 'other': "It is a matter of acting upon the self-made other in such a way as to transform it" (Turner, 1987: 25). At times there is a sense that the teacher identity has already been recognised, however, once these students reflect, as part of the developmental process, on their role this teacher-persona seems strangely unfamiliar: “...it is not actually me teaching... it is like a different person is doing it. You step back and you think, no, they can't have learnt that from me, I am only twenty-one, I can't do that". The initiand standing at the threshold observes herself beyond the threshold: 'the pre-liminal looking at the post-liminal' (Stronach, personal communication).

Many students appeared acutely aware of where they were sited in terms of the 'threshold' and some were able to pinpoint what they believed would make them "proper" teachers. They conjectured that the time they began their first teaching appointment would be the first moment when they would achieve this status. One student reasoned that having a piece of paper confirming that she had a degree would make her a "proper teacher" but later, paradoxically, revealed that although the degree might say she was a "proper teacher" she felt 
she could not be so until she had "experience", had "learnt from mistakes": only then would she have "more idea of what [she is] doing and what the children respond to." Another student used the metaphor of passing the driving test to express exactly the same sentiments. Many stressed not the 'being' but the 'becoming', or striving to 'become', teachers. Turner (1982: 121), developing the work of Schechner suggests that it is in the rehearsal of the role that the various 'selves' eventually synthesise: "The $m e$ the biological, historical individual, the actor, encounters the role given in the script, the not-me; in the crucible of the rehearsal process a strange fusion or synthesis of $m e$ and the not-me occurs".

Students both recognised, the need to reconcile the various ontological dualities and contextual dichotomies, "I think as you get older you become the stereotype because with more practice you become the professional that the 'hand' says you will be" ... yet resisted,

There are four teachers in our house and we have made a pact, we will never wear court shoes as a teacher, we are never going to wear court shoes and three quarter length skirts, and if we do we are getting out of the profession.... I can see myself in twenty years, being that kind of teacher, although I don't want to at the moment. I can see it because that is what I have been used to, you come in fresh from college but you are getting pushed over because that is the way everything goes, that is where the paperwork goes, that is what the Government says - you will be like this.

Thus the performances that students enacted during ITT could be read as ritual observances and having observed the rituals and demonstrated eligibility to enter teacherdom students were given the key. Yet the degree - the symbolic key - which allowed passage did not bestow knowledge of that world. Neither did it, in the eyes of many students, confirm teacher identity: "I don't think you can teach anybody to be a teacher... there is so much in teaching, it is very complex."

\section{Conclusion}

Classic cultural anthropology portrays the liminal stage of transition as one of progressive advancement. We, however, have proposed a model in which the crucial transitional phase is not uniquely resolvable but an extended and ambiguous state of 'in-between-ness' (Bhabha 1994). Bhabha uses the metaphor of 'fold' to represent a 'hybrid liminality' in a way which places the relational possibilities of the pre and post liminal states in a non-exclusive way (Stronach 1996: 396). 'Passage' is not linear but involves a back and forth-ness that repeatedly repositions the initiand in response to a complex, and often contradictory, set of agendas.

Students are required to navigate a path through the 4 year BEd which necessitates a series of changes of state and status between 'student' and 'teacher'. We have shown how students talk of these experiences as a 'game' in a way which captures their sense of 'play' and 'unreality' as they learn to 'define and shape' themselves against a number of different and often conflicting 'ideal' teacher-selves. Dilemmas were apparent in many accounts of student experiences not only between these states but also within them, in attempts to reconcile 'inner' and 'outer' realities, 'real' and 'ideal' teacher selves in the shifting between positions of 'being' and 'becoming'.

Assessment customs experienced in school and university conveyed a number of different, and at times conflicting, messages about student and university tutor identities and positioning. The tutors, whose 'professional worth and integrity' had already been 'deeply undermined' over a number of years (Mahony \& Hextall, 2000), were seen to be further marginalised on a political level by the mode of development, implementation and 
legitimation of the QTS Test. The students had also experienced a number of procedural and ideological changes introduced by the government during their four year course: QTS Numeracy Skills Test (2000), Career Entry Profile (1997), Standards for the Award of QTS (1997) and the skills audits in Maths, English, Science and ICT (1998). Methodologically and professionally the self-audit of knowledge/skills, positioning, as it does, the trainee as professional in control of their own learning, contrasts starkly with the Numeracy Skills Test. The Numeracy Skills test has become an annual ritual for trainee teachers - primary and secondary - across all subject specialisms; and in 2001 the testing was extended to include literacy and ICT. The tests are now taken 'on-line', although the organisational expertise required and the technical glitches experienced in the first year made them no less an administrative nightmare (Hextall et al, 2001). Additional, and perhaps more disturbing ramifications of this most recently imposed ordeal, however, relate to equity and social justice in respect of a number of minority groups such as those with 'English as an Additional Language' [6] (Hextall et al, 2001; TTA, 2000b).

Intended to police the boundaries of the profession and deter the 'other' the implementation of the tests also marks a significant breach in the threshold between student and teacher. For the trials of 'fitness to teach' can extend the liminal state of in-betweenness, as regulations allow for multiple attempts at each. Gratification may thus be deferred through numerous ordeals before QTS status is finally ceded. The student's full (re)incorporation into the profession as teacher may be potentially deferred, or even ultimately barred.

\section{Correspondence to:}

Olwen McNamara, Faculty of Education, University of Manchester, Oxford Road, Manchester M13 9PL. e-mail: olwen.mcnamara@man.ac.uk.

\section{Acknowledgements:}

We are greatly indebted to Gill Hatch, one of the directors of the "amazing production", for her involvement, support and advice during the data collection process. We also acknowledge the support of Brian Corbin, Anne Rowbottom and Ian Stronach for their comments upon an earlier version of the paper. 


\section{NOTES}

[1] The BEd (Bachelor of Education Degree), one of a number of routes into teacher training in the UK, exists alongside the traditional PGCE (Post Graduate Certificate of Education), as a 4-year undergraduate specialist teacher training course. This paper draws on data from a study (ESRC R000223073) that is currently charting the transition of a representative sample of 30 non-maths specialist primary BEd students from their $4^{\text {th }}$ and last year as students through to their first year as primary teachers (Jan 00 - June 01). All 30 students were volunteers: 23 were recruited at the beginning of the $4^{\text {th }}$ year and 7 had been part of an earlier study (ESRC R000222409; reported Brown, T. et al., 1999) and were keen to continue their involvement into the second phase. Full assurances of confidentiality were given to all participants. [N.B. This paper is not a report of the ESRC project itself.]

[2] The data for this paper were gathered during first two phases of interviewing (Jan 2000/April 2000) of the study (R000223073) described above and were analysed using Nvivo, a software package designed for qualitative data analysis. The interviews were semistructured and explored how university/school based training and government policy had shaped students understanding of effective practice, their role as professionals and their image of themselves as (mathematics) teacher. Additional data relating specifically to the Numeracy Skills Test were collected in June 2000 and were drawn from three sources. Firstly, all $2004^{\text {th }}$ year BEd students were requested to complete a short questionnaire survey as they left the test. The questionnaire explored the students' perceptions and feelings about the content, timing, purpose and value of the QTS Numeracy Skills Test (oral and written). A response rate of $20 \%$ was low, but not unexpectedly so, given that after the test a number of the students did not return to the university other than for examinations. Secondly, semistructured interviews were conducted with an opportunity sample of 30 students as they came out of the Skills Test. The schedule was similar to that of the questionnaire but allowed students more flexibility in their response. Thirdly, the main study cohort of 30 students were interviewed by telephone after the Numeracy Skills Test.

[3] England generally scores below average at primary (Reynolds \& Farrell, 1996; Mullis et al., 1997) and secondary level (Beaton et al., 1996; Reynolds \& Farrell, 1996) in terms of international comparisons of number understanding and skills (although interpretations of the statistics have been contested to some degree Brown, 1998) (Brown, M et al.,1999).

[4] In this respect it appears the TTA did not altogether succeed - many tutors in an opportunity sample of mathematics educators involved in mail base discussions on the internet (Autumn 1999; Spring 2000) appeared to feel far from "in touch with developments".

[5] The term has been used in respect of mobile phone users who perform loquaciously but ostensibly for an audience at a distant site (personal communication Brian Corbin).

[6] At the Institute of Education (Didsbury) the Primary BEd and PGCE courses recorded $60 \%$ and $27 \%$, respectively, initial failure rate of minority ethnic students against an overall failure rate of $6 \%$. Hextall, Mahony \& Mentor (2001) raise concerns of the equity of the QTS Test in relation to a number of variables such as ethnicity, gender, class and age. 


\section{BIBLIOGRAPHY}

BEATON, A E, MULLIS, I V S, MARTIN, M O, GONZALEZ, E J, KELLY, D L \& SMITH, T A (1996) Mathematics Achievement in the Middle School Years: IEA's Third Mathematics and Science Study. (Chestnut Hill, Massachusetts, Boston College).

BELL, C (1992) Ritual Theory Ritual Practice. (Oxford, Oxford University Press). BELL, C. (1997) Ritual Perspectives and Dimensions. (Oxford, Oxford University Press). BHABHA, H. (1994) The Location of Culture (London, Routledge) BROWN, M. (1998) The tyranny of the international horse race. In R. Slee \& G. Weiner, with S. Tomlinson (Eds.) School Effectiveness for Whom? Challenges to the school effectiveness and school improvement movements. (London, Falmer Press).

BROWN, M., ASKEW, M., BAKER, D., DENVIR, H. \& MILLETT, A. (1999) Is the national numeracy strategy research-based? British Journal of Educational Studies, 46 (4), pp. 36285.

BROWN, T., MCNAMARA, O., JONES, L. \& HANLEY, U. (1999) Primary Student Teachers' Understanding of Mathematics and its Teaching British Educational Research Journal, 25 (3), pp. 299-322.

BURKE, K. (1973) The Philosophy of Literary Form. (Berkeley, University of California Press).

DfEE (1998) Teaching: High Status, High Standards, Circular 4/98. (London, DfEE). DfEE (1998) Green paper Teachers: meeting the challenge of change (London, DfEE). EISENHART, M; BEHM, L \& ROMAGNANO L. (1991) 'Learning to Teach: developing expertise or rite of passage? Journal of Education for Teaching, 17(1), pp.51-69.

GOFFMAN, E. (1961) Asylums (London, Penguin).

GOFFMAN, E. (1969) The Presentation of Self in Everyday Life (London, Allen Lane). GOFFMAN, E. (1972) Interaction Ritual: essays on face to face behaviour (London, Allen Lane).

HEAD, F. (1992) 'Student Teaching as Initiation into the Teaching Profession' Anthropology \& Education Quarterly, 23(2), pp. 89-107.

HEXTALL, I., MAHONY, P. AND MENTER, I. (2001) 'Just testing?: An analysis of the implementation of 'skills tests' for entry into the teaching profession in England.' Journal of Education for Teaching 27(3), pp. 221-239.

LA FONTAINE, J. (Ed.) (1972) The Interpretation of Ritual. Essays in honour of A.J. Richards (London, Tavistock).

LA FONTAINE, J. (1985) Initiation (Harmondsworth, Penguin).

MAHONY, P. \& HEXTALL, I. (2000) Reconstructing Teaching (London, RoutledgeFalmer) MACALOON, J. (1984) Olympic Games and the Theory of Cultural Performance in j. Macaloon (Ed.) Rite, Drama, Festival, Spectacle. Rehearsals towards a theory of cultural Performance (Philadelphia, PA: Institute for the Study of Human Issues).

MCNALLY, J., COPE, P., INGLIS, B. \& STRONACH, I. (1994) Current Realities in the Student Teaching Experience: A Preliminary Inquiry, Teaching \& Teacher Education, 10 (2), pp. 219-230.

MOORE, S. \& MYERHOFF B. (Eds.) (1977) Secular Ritual (Amsterdam, Van Gorcum). MORRIS, E. (1999) In: TTA (1999) National Skills tests: a guide for trainee teachers (London, TTA).

MULLIS, I. V. S, MARTIN, M. O., BEATON, A. E., GONZALEZ, E. J., KELLY, D. L. \& SMITH, T. A. (1997) Mathematics Achievement in the Primary School Years: IEA's Third Mathematics and Science Study (Chestnut Hill, Massachusetts: Boston College). POWER, M. (1994) The Audit Explosion (London, DEMOS).

POWER, M. (1997) The Audit Society: Rituals of Verification (Oxford, OUP). 
REYNOLDS, D \& FARRELL, S. (1996) Worlds Apart? A review of international surveys of educational achievement involving England (Ofsted Review of Research) (London, HMSO). SCHECHNER, R. \& SCHUMAN, M. (Eds.) (1976) Ritual, play and performance (New York, Seabury Press).

SCHECHNER, R. (1977) Essays on Performance Theory 1970-1976 (New York, Drama Book Specialists).

SINCLAIR, S. (1997) Making Doctors (New York, Berg).

SINGER, M. (1959) Traditional India: structure and change. (Philadelia: American Folk Law Society)

SINGER, M. (1972) When a Great Tradition Modernizes (New York, Praeger).

STRONACH, I. (1988) Vocationalism and economic recovery: the case against witchcraft. In: Education in transition what role for research? (Edinburgh, Scottish Council for Research in Education).

STRONACH, I (1996) Fashioning Post-modernism, Finishing Modernism: tales from the fitting room, British Educational Research Journal, 22 (3), pp. 359-375.

STRONACH, I. (1999) Shouting Theatre in a Crowded Fire: Educational Effectiveness as 'Cultural Performance', Evaluation, 5(2), pp.173-193.

TTA (1997) Career Entry Profile (London, TTA).

TTA (1997) Standards for Qualified Teacher Status (London, TTA).

TTA (1999) National Skills tests: a guide for trainee teachers (London, TTA).

TTA (2000a) QTS Numeracy Skills Test Trainee Support Materials (London, TTA).

TTA (2000b) QTS Skills Test in Numeracy, June and July 2000: National Results Summary for Initial Training Providers. (London, TTA).

TURNER, V. (1977) Variations on a theme of liminality. In: S. Moore \& B. Myerhoff (Eds.) Secular Ritual (Amsterdam, Van Gorcum).

TURNER, V. (1982) From Ritual to Theatre: The Human Seriousness of Play (New York, PAJ).

TURNER, V. (1987) The Anthropology of Performance (New York, PAJ).

VAN GENNEP, A. (1909) Les Rites de Passage (Paris, Emile Nourry).

WHITE, J. (1989) 'Student teaching as a Rite of Passage', Anthropology \& Education Quarterly, 20, pp.177-195.

WINNICOTT, D. (1980) Playing and Reality (Middlesex; New York; Victoria; Auckland, Penguin). 